\title{
Germination of seeds of Tamarix ramosissima
}

\author{
JAMES A. YOUNG, CHARLIE D. CLEMENTS, AND DANIEL HARMON
}

Authors are Rangeland Scientists and Graduate Student Research Assistant, USDA, Agricultural Research Service, 920 Valley Road, Reno, Nev. 895J2. Email address corresponding author jayoung@scs.unr.edu

\section{Abstract}

The germination of seeds of saltcedar (Tamarix ramosissima Ledeb.) was compared at a wide range of constant or alternating temperatures from 0 through $40^{\circ} \mathrm{C}$. Germination temperature profiles were developed for seeds of saltcedar collected from the Walker River Delta in western Nevada over a 3 year period. Germination occurred over a wide range of temperatures. For 2 of the 3 years of testing, maximum germination observed was 98 or $100 \%$, indicating the seed lots were highly viable. Germination ranged from 0 to $6 \%$ at very cold seedbed temperatures, but jumped to 39 to $43 \%$ at cold seedbed temperatures. There was very little difference in germination between moderate and warmer seedbed temperatures. No single temperature always supported optimum germination. The temperatures that most frequently supported optima were $10 / 20\left(10^{\circ} \mathrm{C}\right.$ for 16 hours and $20^{\circ} \mathrm{C}$ for 8 hours in each 24 hour period), 10/25, 15/20, and $35^{\circ} \mathrm{C}$. Mid summer collections of saltcedar seeds were much more variable in germination response compared to annually repeated late spring collections from the Walker River Delta. Available soil moisture apparently is an important factor in the germinability of saltcedar seeds collected in mid summer. Temperature regimes that supported optimum germination for the Walker River Delta accession of seed collected in mid summer, tended to occur at higher temperatures than for seeds collected from the same stand in late spring. Comparison of the saltcedar profile with germination temperature profiles of seeds of tree willow (Salix lutea Nutt.), coyote willow (S. exigua Nutt.), or Fremont cottonwood (Populus fremontii $S$. Watson) revealed that germination of saltcedar seeds was equal in the number of regimes with some germination, mean of optima, and maximum observed germination. For all other germination characteristics measured, saltcedar is lower and sometimes distinctly lower than for seeds of the native woody species.

Key Words: invasive species, seed and seedbed ecology, germination temperature profiles

Saltcedar (Tamarix ramosissima Ledeb.) is a shrub or small tree that is native to Central Asia. It is found in a multitude of plant communities from the Near East to the Caspian Sea area, and across Asia to western China and Korea (Baum 1978). It was imported to western North America for use in ornamental and conservation plantings (Lovich 2000). The taxonomic relations within the genus Tamarix are complex and controversial both for plant material in its native habitat and for the species that have been introduced to North America (Baum 1978). Both Tamarix

Manuscript accepted 6 Feb. 04.

\section{Resumen}

La germinación de semillas de "Saltcedar" (Tamarix ramosissi$m a$ Ledeb.) se comparó en un amplio rango de temperaturas constantes o alternantes de 0 a $40^{\circ} \mathrm{C}$. Se desarrollaron perfiles de temperatura de germinación de semillas de "Saltcedar" colectadas durante 3 años del Delta del Río Walker en el oeste de Nevada. La germinación ocurrió en un amplio rango de temperaturas. En 2 de los 3 años de prueba la germinación máxima observada fue de 98 o $100 \%$, indicando que los lotes de semilla fueron altamente viables. La germinación varió de 0 a $6 \%$ en temperaturas muy frías de la cama de siembra y subió a 39 $43 \%$ en las temperaturas frías de la cama de siembra. Hubo muy poca diferencia en germinación entre las temperaturas moderadas y tibias de la cama de siembra. Ninguna temperatura en particular sostuvo una germinación óptima. Las temperaturas que mas frecuentemente sostuvieron una germinación óptima fueron: $10 / 20\left(10^{\circ} \mathrm{C}\right.$ por 16 horas y $20^{\circ} \mathrm{C}$ por 8 horas en cada periodo de 24 horas.), $10 / 25,15 / 20$ y $3^{\circ} \mathrm{C}$. Las colectas de semillas de "Saltcedar" de mediados del verano fueron mucho mas variables en la respuesta de germinación en comparación con las colectadas a fines de primavera en la Delta del Río Walker. La humedad disponible del suelo aparentemente es un factor importante en la germinabilidad de las semillas de "Saltcedar" colectadas a mediados de verano. Los regímenes de temperatura que sostuvieron una germinación óptima de las semillas colectadas a mediados de verano en el Delta del Río Walker tendieron a ocurrir en temperaturas mas altas que para las semillas colectadas en la misma población de "Saltcedar" a fines de primavera. La comparación del perfil de germinación del "Saltcedar" con los perfiles de temperatura de germinación de semillas de "Tree willow" (Salix lutea Nutt.), "Coyote willow" (S. exigua Nutt.) o "Fremont cottonwood" (Populus fremontii S. Watson) revelaron que la germinación de semillas de "Saltcedar" fue igual en el número de regímenes con algo de germinación, media de las germinación optima y máxima observada. Para todas las otras características de germinación medidas el "Saltcedar" esta abajo y algunas veces distintivamente mas bajo que las especies nativas de plantas leñosas.

chinensis Lour. and $T$. ramosissima have been suggested as the correct taxon for the wide spread saltcedar found in North America. Inter-specific hybridization may have occurred within the plant material found in North America (Wilken 1993).

Saltcedar escaped cultivation and spread in riparian communities throughout much of the southwestern United States and in less extensive stands in many other states. There is considerable debate concerning why saltcedar is such a highly invasive species. It is not clear if saltcedar invasion is the cause of changes in riparian communities or a consequence of changes in stream 
hydrology (Lovich 2000). Regardless, the presence of saltcedar is associated with dramatic changes in geomorphology, ground water availability, soil chemistry, fire frequency, plant community composition, and wildlife diversity (Graf 1978, Busch 1995, Anderson 1996, Sala et al. 1996).

Saltcedar seed production can occur over a 5.5 month period each year, with a major peak in the late spring to early summer (Warren and Turner 1975). The seeds are very small. Baum (1978) reported the dimensions of seeds of $T$. gallica as 0.17 $\mathrm{mm}$ in diameter and $0.45 \mathrm{~mm}$ long. The seeds have short bristle like hairs arranged in a spiral. It has been suggested that these hairs aid in the aerodynamics of the seed for dispersal (Lovich 2000). They also may aid in buoyancy for water dispersal or in anchoring the seeds to seedbeds. In microscopic examination of germinating seedlings, we determined the embryonic saltcedar plants to be translucent with the primordial vascular system visible. A ring of hairs occurred around the hypocotyl (unpublished research USDA-ARS, Reno, Nev.). These hypocotyl hairs may be important in anchoring seedlings to the seedbed. (Young and Martens 1991).

Saltcedar plants readily regenerate from crown and root sprouts following mechanical removal or burning of the aerial portions of the plant. Stream bank erosion can result in the transportation of stem or root fragments that may root and establish new infestations. The overwhelming means of spread of saltcedar is by seedling establishment. Seed production may exceed one half million seeds per plant during a single season (Lovich 2000). We have recorded saltcedar seed rain of 4,600 seeds per $\mathrm{m}^{2}$ in saltcedar infestations, 2,400 seeds per $\mathrm{m}^{2} 0.1 \mathrm{~km}$ down wind, and 51 seeds per $\mathrm{m}^{2} 8 \mathrm{~km}$ down wind from infestations. The sticky traps were exposed for 1 week during the initial late spring dispersal period in the Walker River Delta (unpublished research USDA, Agricultural Research Service, Reno, Nev.). Saltcedar seedlings emerge within 24 hours of planting seeds in warm moist soil (Merkel and Hopkins 1957). Our experience with saltcedar seeds in Perti dishes in the laboratory is that the germination process is nearly instantaneous after the seeds imbibe water (unpublished research USDA, Agricultural Research Service, Reno, Nev.). Saltcedar seed germination is not markedly reduced by osmotic potentials reduced by salt $(\mathrm{NaCl})$ (Shafroth et al. 1995). Considering how important seeds are in the invasive ecology of most Tamarix species, very little is known about the seed ecology of these plants (Young and Young 1992). A major reasons for this lack of studies of seeds of saltcedar are: 1) they are minute in size making seed collection and counting very difficult, and 2) the seeds have a very short period of viability after maturity (Reynolds and Alexander 1974). Germination trials with saltcedar seeds have to be conducted as soon as they mature. All of these factor combine to apparently make saltcedar unpopular subject for seed ecology research.

Our purpose was to compare the germination of saltcedar seeds over a wide range of temperatures. We have conducted previous studies on the native woody species that saltcedar has replaced in river systems in the Great Basin and that hopefully will replace the invasive species if current biological control trials are successful (Young and Clements 2003a, 2003b).

\section{Materials and Methods}

Seeds of saltcedar were collected from trees growing in the delta of the Walker River (Latitude N $38^{\circ} 46^{\prime}$, Longitude W $118^{\circ} 46^{\prime}$ ) in western Nevada. The elevation of the delta is $1200 \mathrm{~m}$. Seeds were collected in early June when the first saltcedar seeds of the season were mature. The collection time corresponds to the period when seeds of Fremont cottonwood (Populus fremontii S. Watson) and willow (Salix spp.) species are mature and being dispersed. Collections were made in 1999 , 2000 , and 2001. Seeds collections were combined from numerous trees. A handful of saltcedar seeds stripped from a single inflorescence can contain thousands of seeds. Combining many handfuls from numerous plants with the seed collections thoroughly mixed resulted in a population of tens of thousands of seeds from which the seeds for experimentation were randomly picked. The seeds were immediately transported to the laboratory, threshed and cleaned by hand and the germination test conducted.

In 2001, saltcedar seeds were also collected at the Humboldt Sink (Latitude N $40^{\circ} 26^{\prime}$, Longitude W $\left.118^{\circ} 30^{\prime}\right)(1230 \mathrm{~m}$ elevation) in northern Nevada, the Stillwater Sink in western Nevada (Latitude N $39^{\circ} 40^{\prime}$, Longitude W $118^{\circ}$ 30') (1220 m elevation) and in the Owens River Valley in southeastern California (Latitude N $37^{\circ} 53^{\prime}$, Longitude W $118^{\circ}$ $\left.30^{\prime}\right)$ (1190 m elevation).

In all experiments 4 replications of 25 seeds each were used in a randomized block design. Seeds were placed on top of non-toxic commercial germination paper in closed Petri dishes and kept wet with tap water. Germination trials were conducted in the dark. Incidental light was received during initial wetting and germination counts. Seeds were considered germinated when the radical emerged $1 \mathrm{~mm}$. Germination counts were made after 1, 2, and 4 weeks. Constant incubation temperatures were 0,2 , and $5^{\circ} \mathrm{C}$ and at 5 degree increments through $40^{\circ} \mathrm{C}$. Alternating regimes included 16 hours at each constant temperature, plus 8 hours at each possible higher temperature per 24 hours. For example, $35^{\circ} \mathrm{C}$ alternated with $40^{\circ} \mathrm{C}$ only, while $0^{\circ} \mathrm{C}$ alternated with $2,5,10$, $15,20,25,30,35$, and $40^{\circ} \mathrm{C}$. This made a total of 55 constant and alternating temperature regimes (Young et al. 1991).

The germination responses of the accessions of saltcedar were compared using the following seedbed temperature regime definitions (Young and Evans 1982):

a. Very cold: $0 / 0$ (constant $0^{\circ} \mathrm{C}$ ), $0 / 2\left(0^{\circ}\right.$ $\mathrm{C}$ for 16 hours and $2^{\circ} \mathrm{C}$ for 8 hours in each 24 hour), $0 / 5$ and $2 / 2^{\circ} \mathrm{C}$.

b. Cold: $0 / 10,0 / 15,2 / 5,2 / 10,2 / 15,5 / 5$ and $5 / 10^{\circ} \mathrm{C}$

c. Cold fluctuating: $0 / 20$ through $0 / 40^{\circ} \mathrm{C}$ and $2 / 20$ through $2 / 40^{\circ} \mathrm{C}$.

d. Fluctuating: $5 / 35$ through $5 / 40^{\circ} \mathrm{C}$, $10 / 35,10 / 40$, and $15 / 40^{\circ} \mathrm{C}$.

e. Moderate: $5 / 20$ through $5 / 30,10 / 10$ through $10 / 30^{\circ} \mathrm{C}, 15 / 15$ through $15 / 35^{\circ}$ C, $20 / 20$ through $30 / 35^{\circ} \mathrm{C}$, and $25 / 25$ through $25 / 30^{\circ} \mathrm{C}$.

f. Warm: $20 / 40,25 / 35$, and $25 / 40^{\circ} \mathrm{C}$ $30 / 30$ through $30 / 40^{\circ} \mathrm{C}, 35 / 35,35 / 40$ and $40 / 40^{\circ} \mathrm{C}$.

The temperature categories reflect germination environments of field seedbeds based on several years of monitoring in the Great Basin (Evans et al. 1970, Evans and Young 1970, 1972).

For comparing optimum temperatures for germination we calculated degree hours per day above $0^{\circ} \mathrm{C}$. For example a constant $2^{\circ} \mathrm{C}$ there would be 48 degree hours in each 24 hours.

Data from each base temperature and its alternating temperature regimes were used to generate a quadratic response surface with estimated means and confidence intervals at the $1 \%$ level of probability (Young et al. 1980, Evans et al. 1982, Palmquist et al. 1987). A number of germination parameters were calculated from the quadratic response surfaces (Table l) (Young and Evans 1982). These germination parameters were individually subjected to analysis of variance and the means separated by Duncan's Multiple Range Test. 


\begin{tabular}{|c|c|c|}
\hline Calculated parameter & Derived parameter & Purpose \\
\hline \multicolumn{3}{|l|}{ Calculated within profile } \\
\hline Mean germination & Sum divided by 55 & Gross comparison of profiles \\
\hline Percentage of regimes with germination & Number with germination divided by 55 & Indication of breath of germination response \\
\hline Percentage of regimes with optimum & $\begin{array}{l}\text { Number of regimes with germination no less than } \\
\text { maximum observed minus confidence interval divided } \\
\text { by } 55\end{array}$ & $\begin{array}{l}\text { Indication of breath of temperatures } \\
\text { that support optimum germination }\end{array}$ \\
\hline Mean of optima & Sum of optima divided by number of optima & Provides measure of potential germination \\
\hline Optimum germination & Highest observed germination & Indication of potential viability \\
\hline \multicolumn{3}{|l|}{ Calculated among germination profiles } \\
\hline Frequency of optima & $\begin{array}{l}\text { Times temperature regime supports optima } \\
\text { divided by total number of profiles }\end{array}$ & $\begin{array}{l}\text { Provides an estimate of optimum temperture } \\
\text { for germination with statistical precision }\end{array}$ \\
\hline
\end{tabular}

\section{Results}

\section{Germination Temperature Profile}

A representative germination temperature profile for seeds of saltcedar (Table 2), indicates some germination occurred over a wide range of temperatures. Only at very cold temperatures $\left(0\right.$ and $\left.2^{\circ} \mathrm{C}\right)$, cold extreme fluctuating $\left(0 / 40^{\circ} \mathrm{C}\right)$, and a very warm $40^{\circ} \mathrm{C}$ failed to produce any germination for the seeds harvested in the Walker River Delta in 1999. The maximum germination occurred in moderate temperature regimes. In our experience, the levels of germination observed were high for seeds of shrubs collected from wildland stands (Young and Young 1992).

\section{Variation In Germination Among Years}

There were no significant $(\mathrm{P}<0.01)$ differences among the 3 years of seed production in mean profile germination or temperature regimes with some germination (Table 3). The mean of the optima varied because the maximum germination observed was significantly higher in 2000 and 2001 compared to 1999 . Saltcedar inflorescenes are extremely indeterminate in flowering. When you strip seeds from the inflorescenes it is difficult to separate the mature from immature seeds, especially considering the very small size of the seeds. Perhaps, the increase in observed maximum germination and mean of the optima, both of which provide a measure of the viability of the seeds, is a product of our increased skill in handling the seeds as the experiment proceeded. Maximum germination of 100 and $98 \%$ that was observed in 2000 and 2001, indicate the seeds of saltcedar can be highly viable.

\section{Categories of Seedbed Temperatures}

Germination ranged from 0 to $6 \%$ at the very cold category of seedbed temperatures (Table 3). Germination increased to 39 to $43 \%$ at cold seedbed temperatures. There was no marked depression in germination at warmer seedbed temperatures compared to moderate temperatures.

\section{Frequency Of Optima}

When comparing multiple profiles for seeds of the same species, the frequency that a given temperature supports optimum germination provides an excellent measure of which incubation temperatures are most suited to the requirements of the particular seeds. Temperatures that supported optimum germination for seeds of saltcedar collect over a 3 year period from the Walker River Delta were spread across 20 temperature regimes or $36 \%$ of the total number of regimes tested (Table 4). No single regime always supported optimum germination. You had to reach at least $15^{\circ}$ C warm period temperatures before optimum germination occurred and that only happen once at $10 / 15^{\circ} \mathrm{C}$. If warm period temperatures were increased to $20 \mathrm{C}$, optima occurred from 0 through $20^{\circ} \mathrm{C}$ cold period temperatures. At $20^{\circ} \mathrm{C}$ warm period temperatures, 10 and $15^{\circ} \mathrm{C}$ cold period temperatures supported optimum germination two thirds of the time. The only other temperatures that supported optima two thirds of the time were $10 / 25^{\circ} \mathrm{C}$, obvious-

Table 2. Quadric response surface with calculated percentage germination and confidence interval $(P<0.01)$ for seeds of saltcedar incubated at 55 constant or alternating temperatures. Seeds collected from Walker River Delta on 9 June 1999. Test conducted immediately after collection. ${ }^{1}$

\begin{tabular}{|c|c|c|c|c|c|c|c|c|c|c|}
\hline \multirow{2}{*}{$\begin{array}{l}\text { Cold period } \\
\text { temperature }\end{array}$} & \multicolumn{10}{|c|}{$\begin{array}{c}\text { Percentage germination } \\
\text { Warm period temperature }{ }^{\circ} \mathrm{C}\end{array}$} \\
\hline & 0 & 2 & 5 & 10 & 15 & 20 & 25 & 30 & 35 & 40 \\
\hline${ }^{\circ} \mathrm{C}$ & & -1-n- & - - - - & - & - & --- & - & --------" & --------- & ------ \\
\hline 0 & $0+10$ & $1 \pm 9$ & $21 \pm 7$ & $47 \pm 6$ & $62 \pm 7$ & $69 \pm 7^{*}$ & $66 \pm 7$ & $53 \pm 7$ & $31 \pm 8$ & $0+10$ \\
\hline 2 & & $0+10$ & $20 \pm 7$ & $47 \pm 6$ & $63 \pm 6$ & $71 \pm 6^{*}$ & $68 \pm 6$ & $57 \pm 5$ & $36 \pm 6$ & $5 \pm 10$ \\
\hline 5 & & & $18 \pm 9$ & $46 \pm 5$ & $64 \pm 5$ & $72 \pm 5^{*}$ & $71 \pm 5^{*}$ & $61 \pm 5$ & $41 \pm 5$ & $12 \pm 8$ \\
\hline 10 & & & & $41 \pm 7$ & $73 \pm 5^{*}$ & {$\left[74 \pm 5^{*}\right]$} & $66 \pm 5$ & $48 \pm 5$ & $48 \pm 5$ & $21 \pm 7$ \\
\hline 15 & & & & & $57 \pm 8$ & $70 \pm 6 *$ & $75 \pm 5^{*}$ & $68 \pm 5$ & $52 \pm 6$ & $28 \pm 8$ \\
\hline 20 & & & & & & $64 \pm 8 *$ & $70 \pm 6^{*}$ & $66 \pm 5$ & $53 \pm 5$ & $31 \pm 8$ \\
\hline 25 & & & & & & & $63 \pm 8$ & $62 \pm 5$ & $51 \pm 5$ & $30 \pm 8$ \\
\hline 30 & & & & & & & & $54 \pm 8$ & $45 \pm 6$ & $27 \pm 8$ \\
\hline 35 & & & & & & & & & $37 \pm 9$ & $21 \pm 9$ \\
\hline 40 & & & & & & & & & & $0 \pm 10$ \\
\hline
\end{tabular}

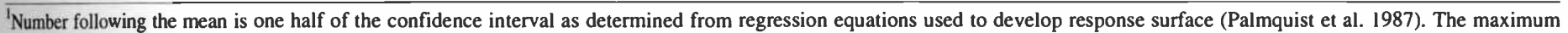

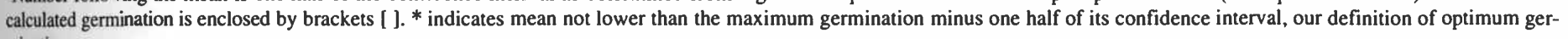
mination. 
Table 3. Comparison of germination temperature profiles for seeds of saltcedar collected in the Walker River Delta in 1999, 2000, and 2001.'

\begin{tabular}{|c|c|c|c|}
\hline \multirow[t]{2}{*}{ Profile characteristic } & \multicolumn{3}{|c|}{ Years of seed production } \\
\hline & 1999 & 2000 & 2001 \\
\hline & \multicolumn{3}{|c|}{ 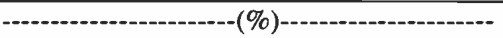 } \\
\hline Profile mean & 43 & 57 & 48 \\
\hline Regimes with some germination & 95 & 93 & 91 \\
\hline Mean of optima & $7 \mathrm{lb}$ & $100 \mathrm{a}$ & $95 \mathrm{a}$ \\
\hline Regimes with optima & $16 \mathrm{~b}$ & $20 \mathrm{~b}$ & $5 \mathrm{~b}$ \\
\hline Maximum observed & $74 b$ & $100 \mathrm{a}$ & $98 \mathrm{a}$ \\
\hline \multicolumn{4}{|l|}{ Categories of seedbed temperature } \\
\hline Very cold & 6 & 2 & 0 \\
\hline Cold & 43 & 42 & 39 \\
\hline Cold fluctuating & $46 \mathrm{~b}$ & $66 a$ & $67 a$ \\
\hline Fluctuating & $37 \mathrm{c}$ & $75 a$ & $52 \mathrm{~b}$ \\
\hline Warmer & 64 & 71 & 63 \\
\hline Moderate & $62 \mathrm{~b}$ & $87 a$ & $66 \mathrm{~b}$ \\
\hline
\end{tabular}

'Means within rows followed by the same letter are not significantly different at the 0.01 level of probability as determined by Duncan's Multiple Range Test. No letter indicate no significant differences.

ly a related temperature, and the outlier constant $35^{\circ} \mathrm{C}$ regime. Constant 20 through $35^{\circ} \mathrm{C}$ regimes supported optima at least once ( $20 \%$ of total) while the remaining temperature regimes were all alternating regimes including the cold fluctuating $0 / 30^{\circ} \mathrm{C}$.

\section{Germination of Saltcedar Seeds Collected In Mid Summer}

When we compared the germination of the saltcedar seeds collected in mid summer from 4 widely spaced locations in the western Great Basin, there were marked differences in many germination categories among locations and with the late spring collections from the Walker River Delta (Tables 3 and 5). Compared to the 3 years of seed collections made in the Walker River Delta, the mid summer seed collections from the same plants had much lower germination (Tables 3 and 5). The maximum observed germination was considerably lower for the mid summer col- lection as well as the regimes with some germination. Seeds collected from the Carson Sink in mid summer germinated similar to those collected from the Walker River Delta. Saltcedar seeds collected in mid summer in the Humboldt Sink had generally equal or higher germination than observed for late spring seed collections in the Walker River Delta. The Humboldt Sink seeds were the only accession with marked germination at the very cold category of seedbed temperatures (Tables 3 and 5). Seeds collected at the Owens Valley site had germination profiles similar to those observed for late spring collections in the Walker River Delta.

The timing of the collection of saltcedar seeds, late spring when the first seeds are mature versus mid summer, is not as critical as how much soil moisture is available. When the mid summer collections were made in the Walker River Delta, the river was completely dry and flow from the previous winter was very limited. The Carson Sink site was also very dry when the col- lection was made. The Humboldt Sink site does not have surface water, but apparently the ground water level is maintained by adjacent irrigated fields.

\section{Optimum Temperatures For Germination Of Seeds Collected In Mid Summer}

Temperature regimes that supported optimum germination for the 4 accessions of saltcedar seed collected in mid summer occurred at $70 \%$ of the regimes tested (data not shown). For the seeds collected in mid summer in the Walker River Delta we compared frequency of optima with the late spring collected accessions (Table 6 ). The mid summer collected seeds overlapped with the late spring collected seeds at $20 / 25^{\circ} \mathrm{C}$, but other optima were at warmer temperature regimes.

\section{Comparison Of Saltcedar With Seeds Of Native Woody Species}

We previously conducted germination temperature profiles for tree willow (Salix lutea Nutt.) and coyote willow (S. exigua Nutt.) (Young and Clements 2003a), and Fremont cottonwood (Populus fremontii S. Watson) (Young and Clements 2003b). The seeds for these species were also collected in the Walker River Delta in the late spring at the same time the saltcedar seeds were collected. Seeds of the willow species mature first, Fremont cottonwood starts slightly later, and saltcedar overlaps with the end of the Fremont cottonwood seed dispersal, but they continue to disperse all summer. Comparison of the temperature germination profiles for all 4 species revealed that generally of saltcedar seeds have lower germination than seeds of the native woody species (Table 7). This is true for profile mean, temperature regimes

Table 4. Frequency that a temperature regime supported optimum germination for seeds of saltcedar collected in the Walker River Delta in 1999, 2000, and 2001.

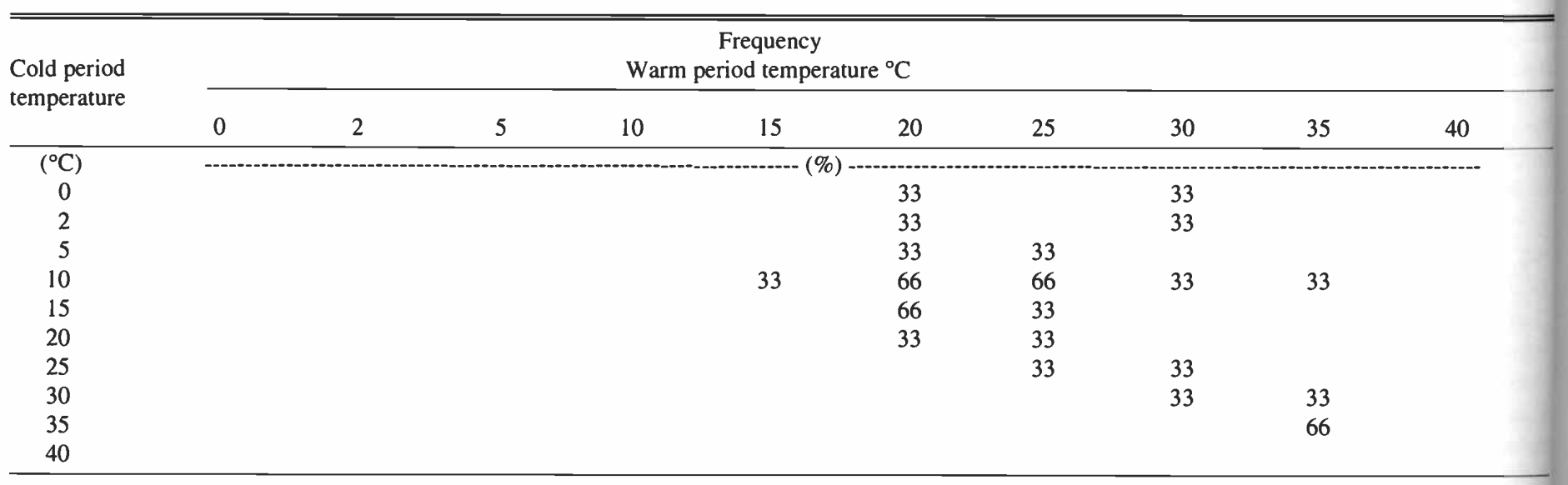


Table 5. Comparison of germination temperature profiles for seeds of saltcedar collected in mid summer 2001 from 4 locations in the Great Basin. ${ }^{1}$

\begin{tabular}{|c|c|c|c|c|}
\hline \multirow[t]{2}{*}{ Profile characteristics } & \multicolumn{4}{|c|}{ Locations } \\
\hline & $\begin{array}{l}\text { Walker } \\
\text { Delta }\end{array}$ & $\begin{array}{l}\text { Humboldt } \\
\text { Sink }\end{array}$ & $\begin{array}{c}\text { Carson } \\
\text { Sink }\end{array}$ & $\begin{array}{l}\text { Owens } \\
\text { Valley }\end{array}$ \\
\hline & \multicolumn{4}{|c|}{ - - } \\
\hline Profile mean & $13 c$ & $87 \mathrm{a}$ & $16 c$ & $46 b$ \\
\hline Regimes with some germination & $75 b$ & $96 a$ & $96 a$ & $86 a b$ \\
\hline Mean of optima & $44 \mathrm{~b}$ & $99 a$ & $35 \mathrm{~b}$ & $98 \mathrm{a}$ \\
\hline Regimes with optima & $11 b$ & $82 \mathrm{a}$ & $15 \mathrm{~b}$ & $9 \mathrm{~b}$ \\
\hline Maximum observed & $50 \mathrm{~b}$ & $100 \mathrm{a}$ & $43 b$ & $100 \mathrm{a}$ \\
\hline \multicolumn{5}{|c|}{ Categories of seedbed temperatures } \\
\hline Very cold & $\mathrm{Ob}$ & $64 a$ & $3 b$ & $0 \mathrm{~b}$ \\
\hline Cold & ob & $96 a$ & $20 \mathrm{~b}$ & $20 \mathrm{~b}$ \\
\hline Cold fluctuating & $16 \mathrm{~b}$ & $91 \mathrm{a}$ & $25 \mathrm{~b}$ & $81 \mathrm{a}$ \\
\hline Fluctuating & $10 c$ & $94 a$ & $22 c$ & $66 b$ \\
\hline Warmer & $29 c$ & $88 \mathrm{a}$ & $22 \mathrm{c}$ & $43 b$ \\
\hline Moderate & $25 \mathrm{c}$ & $99 a$ & $28 \mathrm{c}$ & $67 \mathrm{~b}$ \\
\hline
\end{tabular}

Means within rows followed by the same letter are not significantly different at the 0.01 level of probability as determined by Duncan's Multiple Range Test. No letter indicate no significant differences.

with optimum germination and for most of the seedbed temperature categories. There are important exceptions. There were no differences among species in temperature regimes that produced some germination, mean of the optima, and maximum germination observed. The data presented are the average of 3 years data $(1999,2000$, and 2001), except for the willow species where 2000 was not used because seed quality was severely lowered by an unusually severe late frost. The germination of Fremont cottonwood and saltcedar seeds was not severely lowered by this frost, remember they mature later. This may have great seed ecology significance.

\section{Frequency Of Optima For Saltcedar and The Native Woody Species}

Plotting the temperature regimes with the highest frequency of supporting optimum germination (Table 8), reveals over-
Remember this applies to the highest frequency of the occurrence of optima. Saltcedar seeds had optima occur at least once at all constant temperatures from 20 through $35^{\circ} \mathrm{C}$. Obviously, the seeds of all these species tend to have their ultimate best germination at temperature regimes with diurnal fluctuations. The extreme in diurnal fluctuations would be coyote willow seeds at $0 / 35$ or $2 / 35^{\circ} \mathrm{C}$.

\section{Discussion}

Saltcedar seeds obviously can germinate over a wide range of constant or alternating temperatures. The same is true for the 3 species of native woody plants found in the Walker River Delta. Saltcedar has no great advantage over seeds of the native woody species in this aspect of germination ecology. Saltcedar seeds have relatively high germination at specific incubation temperatures, but not as high as seeds of the native species that occasionally reached $100 \%$ germination at specific temperatures. Again there is no clear-cut advantage apparent for seeds of the exotic, invasive species.

The native species have very specific and relatively short periods of seed dispersal in late spring, while saltcedar seed production can continue for the entire summer. The germination characteristics of saltcedar seeds produced in mid summer may be strikingly different from those dispersed in late spring near the end of seed dispersal by the native woody species. The prolonged seed production and dispersal by saltcedar during the summer months is only an advantage over the exotic species if moist seedbeds suitable for germination exist at the time of seed dispersal. Remember, the half life of these seeds is apparently very short under field conditions

Table 6. Comparison of frequency of optimum germination for seeds of saltcedar collected in late spring $(*)$ versus seeds collected in mid summer $(+)$ from the Walker River Delta.

\begin{tabular}{|c|c|c|c|c|c|c|c|c|c|c|c|}
\hline \multirow{2}{*}{$\begin{array}{l}\text { Cold period } \\
\text { temperature }\end{array}$} & \multicolumn{10}{|c|}{$\begin{array}{c}\text { Frequency } \\
\text { Warm period temperature }{ }^{\circ} \mathrm{C}\end{array}$} & \\
\hline & 0 & 2 & 5 & 10 & 15 & 20 & 25 & 30 & 35 & 40 & \\
\hline$\left({ }^{\circ} \mathrm{C}\right)$ & - & 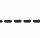 & - & - & --- & - & ---- & --- & 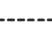 & $--\cdot-$ & \\
\hline 0 & & & & & & $*$ & & $*$ & & & . \\
\hline 2 & & & & & & $*$ & & $*$ & & & \\
\hline 5 & & & & & & $*$ & $*$ & & & & \\
\hline 10 & & & & & $*$ & $*$ & $*$ & $*$ & $*$ & & \\
\hline 15 & & & & & & $*$ & $*$ & & + & & \\
\hline 20 & & & & & & & $*$ & $*$ & + & + & \\
\hline 25 & & & & & & & $*$ & $*$ & + & + & \\
\hline 30 & & & & & & & & $*$ & $*$ & + & \\
\hline 35 & & & & & & & & & $*$ & & \\
\hline 40 & & & & & & & & & & & \\
\hline
\end{tabular}


Table 7. Comparison of germination temperature profiles for saltcedar, tree and coyote willow ${ }^{\mathbb{1}}$, and Fremont cottonwood ${ }^{2}$ from the Walker River Delta. All seeds collected in late spring.

\begin{tabular}{lcccc}
\hline \hline Profile characteristics & \multicolumn{4}{c}{ Species } \\
& Saltcedar & $\begin{array}{c}\text { Tree } \\
\text { willow }\end{array}$ & $\begin{array}{c}\text { Coyote } \\
\text { willow }\end{array}$ & $\begin{array}{c}\text { Fremont } \\
\text { cottonwood }\end{array}$ \\
\hline & $-13 \mathrm{c}$ & $87 \mathrm{a}$ & $16 \mathrm{c}$ & $46 \mathrm{~b}$ \\
Profile mean & $13 \mathrm{c}$ & $69 \mathrm{a}$ & $72 \mathrm{a}$ & $74 \mathrm{a}$ \\
Mean & $49 \mathrm{~b}$ & 96 & 95 & 94 \\
Regimes with some germination & 93 & 98 & 96 & 97 \\
Mean of optima & 89 & $40 \mathrm{a}$ & $59 \mathrm{a}$ & $56 \mathrm{a}$ \\
Regimes with optima & $14 \mathrm{~b}$ & 100 & 100 & 100 \\
Maximum observe & 91 & & & \\
& & & & \\
Categories of seedbed temperatures & & $11 \mathrm{~b}$ & $14 \mathrm{~b}$ & $36 \mathrm{a}$ \\
$\quad$ Very cold & $3 \mathrm{c}$ & $74 \mathrm{~b}$ & $93 \mathrm{a}$ & $92 \mathrm{a}$ \\
Cold & 41 & $80 \mathrm{a}$ & $84 \mathrm{a}$ & $89 \mathrm{a}$ \\
Cold fluctuating & $60 \mathrm{~b}$ & $73 \mathrm{a}$ & $72 \mathrm{a}$ & $89 \mathrm{a}$ \\
Fluctuating & $55 \mathrm{c}$ & $82 \mathrm{a}$ & $84 \mathrm{a}$ & $52 \mathrm{~b}$ \\
Warmer & $64 \mathrm{~b}$ & $94 \mathrm{a}$ & $90 \mathrm{a}$ & $92 \mathrm{a}$ \\
$\quad$ Moderate & $72 \mathrm{~b}$ & &
\end{tabular}

${ }^{1}$ Tree willow (Salix lutea Nutt.) and coyote willow (S. exigua Nutt.) data from Young and Clements (2003a).

${ }^{2}$ Fremont cottonwood (Populus fremontii S. Watson) data from Young and Clements (2003b).

${ }^{3}$ Means within rows followed by the same letter are not significantly different at the 0.01 level of probability as determined by Duncan's Multiple Range Test.

and appreciable seedbanks are not built.

The seeds of the native woody species and especially those of coyote willow had optimum germination most frequently at cool to cold, widely fluctuating temperatures. In the northern Great Basin, such diurnal temperatures extremes occur in late spring and early summer when day time temperatures are sufficiently high to warm seedbeds (Evans et al. 1970). Much has been made of the germination of saltcedar seeds under osmotic potentials low enough to inhibit the germination of seeds of native woody species (Shafroft et al. 1995). For seeds of desert saltgrass [Distichlis spicata var. stricta (Torr.) Beetle] growing in environments of the western Great Basin that were very similar to those found in the saltcedar infestations of the Walker River Delta, Cluff et al (1983) found that by the time in the season when day time temperatures allowed for sufficient diurnal fluctuations to allow germination of seeds of this species, osmotic potentials of the seedbeds were too low to allow germination. They concluded that seedling establishment of desert saltgrass is probably extremely episodic and was conditioned by unusual moisture events. Seeds of the willow species mature and disperse 2 weeks to a month before seed dispersal occurs for saltcedar in the Walker River Delta. This is apparently an establishment advantage in avoiding osmotic stress in moist seedbeds, but early maturing seeds can be injured by late frost.
The tremendous seed production potential of individual saltcedar plants underscores the importance of control potential seed source trees even if they occur in low densities and are widely dispersed. The occurrence of seedbed conditions that will support germination of saltcedar may be highly infrequent, but annual seed rain of the species insures huge amounts of seeds will be dispersed to suitable seedbeds. In the Humboldt Sink, historic levels of flooding occurred during the 1980s. As the flood waters receded from former cultivated fields a very few saltcedar plants located on levies, apparently provided a seed rain that resulted in remarkably uniform seedling establishment over several thousand hectares. If these few trees had been removed before the flood, saltcedar seeds would have required dispersal from much greater distances. Another practical management application of this seed research is not to give up on natural seedling establish of the native woody species. On moist seedbeds without highly negative osmotic potentials, the highly germinable seeds of the native woody species might have a chance of establishment

\section{Literature Cited}

Anderson, B.W. 1996. Saltcedar, revegetation and riparian ecosystems in the Southwest. pp. 32-41 In: J. E.Lovich, J. Randall, and M. Kelly (eds.) Proc. California Exotic Pes Plant Council Sym. 1995. Davis, Calif.

Baum, B.R. 1978. The genus Tamarix. Israel Academy of Sciences and Humanities, Te Aviv, Israel.

Busch, D.F. 1995. Effects of fires on southwestern riparian plant community structure Southw. Nat. 40:259-267.

Table 8. Comparison of temperatures that supported most frequently optimum germination for tree willow ${ }^{1}$ (T), coyote willow ${ }^{1}(C)$, Fremont cotton$\operatorname{wood}^{2}(F)$, saltcedar (S) based on germination temperature profiles conducted on seeds collected from the Walker River Delta in late spring for? consecutive years.

\begin{tabular}{|c|c|c|c|c|c|c|c|c|c|c|}
\hline \multirow{2}{*}{$\begin{array}{l}\text { Cold period } \\
\text { temperature }\end{array}$} & \multicolumn{9}{|c|}{$\begin{array}{c}\text { Frequency } \\
\text { Warm period temperature }{ }^{\circ} \mathrm{C}\end{array}$} & \multirow[b]{2}{*}{40} \\
\hline & \multirow[t]{2}{*}{0} & 2 & 5 & 10 & 15 & 20 & 25 & 30 & 35 & \\
\hline$\left({ }^{\circ} \mathrm{C}\right)$ & & & & & 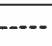 & -...-... & - & -......... & $\cdots$ & $\cdots$ \\
\hline 0 & & & & & C & $\mathrm{C}$ & $\mathrm{C}$ & & $\mathrm{C}$ & \\
\hline 2 & & & & $\mathrm{C}$ & C & C & C, F & C, F & C & \\
\hline 5 & & & & & C & C & C & & & \\
\hline 10 & & & & C & C & $S$ & $S$ & & & \\
\hline 15 & & & & & & C, S & $\mathrm{T}$ & $\mathrm{T}$ & & \\
\hline 20 & & & & & & & & $\mathrm{C}$ & & \\
\hline 25 & & & & & & & & & & \\
\hline 30 & & & & & & & & & & \\
\hline 35 & & & & & & & & & $S$ & \\
\hline 40 & & & & & & & & & & \\
\hline
\end{tabular}

Tree willow (Salix lutea Nutt.) and coyote willow (S. exigua Nutt.) data from Young and Clements (2003a).

${ }^{2}$ Fremont cottonwood (Populus fremontii S. Watson) data from Young and Clements (2003b). 
Cluff, G.J., R.A. Evans, and J.A. Young. 1983. Desert saltgrass seed germination and seedbed ecology. J. Range Manage. 36:419-422.

Evans, R.A. and J.A. Young. 1970. Plant litter and establishment of alien annual species in rangeland communities. Weed Sci. 18:697-703.

Evans, R.A. and J.A. Young. 1972. Microsite requirements for establishment of alien annual species in rangeland communities. Weed Sci. 20:350-356.

Evans, R.A., D.A. Easi, D.N. Book, and J.A. Young. 1982. Quadratic response surface analysis of seed germination trials. Weed Sci. 30:411-416.

Evans, R.A., H.R. Holbo, R.E. Eckert, Jr., and J.A. Young. 1970. Functional environment of downy brome communities in relation to weed control and revegetation. Weed Sci. 18:154-162.

Graf, W.L. 1978. Fluvial adjustments to the spread of tamarisk in the Colorado Plateau region. Geological Soc. Amer. Bull. 89:1491-1501.

Lovich, J. 2000. Tamarix parviflora. pp. 313-317. In: C. C. Bossard, J. M. Randall, and M. C. Hosbovsky (eds.) Invasive Plants of California Wildlands. Univer. California Press, Berkeley, Calif.
Merkel, D.L. and H.H. Hopkins. 1957. Life history of saltcedar (Tamarix gallica L.) Trans. Kansas Acad. Sci. 60:360-369.

Palmquist, D.E., R.A. Evans, and J.A. Young. 1987. Comparative analysis of temperature response surfaces. pp. 97-103 In: G. W. Frasier and R. A. Evans (eds.) Seed and Seedbed Ecology of Rangeland Plants. USDA, Agr.. Res. Ser., Washington, D.C.

Reynolds, H.G. and R.R. Alexander. 1974. Tamarix. pp. 420-421 In: Seeds of woody plants in the United States. Handb. 450, USDA, Forest Service, Washington, D. C.

Sala, A., S.D. Smith, and D.A. Devitt. 1996. Water use by Tamarix ramosissima and associated phreatophytes in a Mojave Desert floodplain. Ecol. Appl. 6:888-898.

Shafroth, P.B., J.M. Friedman, and L.S. Ischinger. 1995. Effects of salinity on establishment of Populus fremontii (cottonwood) and Tamarix ramosissima (saltcedar) in southwestern United States. Great Basin Nat, 55:58-65.

Warren, D.K. and R.M. Turner. 1975. Saltcedar (Tamarix chinensis) seed production, seedling establishment, and responses to inundation. J. Arizona Acad. Sci. 10:135-144.

Wilken, D.H. 1993. Tamaricaceae. P. 1080. In: J. C. Hickman (ed.) The Jepson Manual. Univer. California Press, Berkeley, Calif.
Young, J.A. and C.D. Clements. 2003a. Seed germination of willow species from a desert riparian system. J. Range Mange. 56:496-500.

Young, J.A. and C.D. Clements. 2003b. Germination of seeds of Fremont cottonwood. J. Range Manage.56:660-664.

Young, J.A. and R.A. Evans. 1982. Temperature profiles for germination of cool season grasses. ARR-W-72, USDA, ARS, Oakland, Calif. 92 p.

Young, J.A. and E. Martens. 1991. Importance of hypocotyl hairs in germination of Artemisia seeds. J. Range Manage. 44:438-442.

Young, J.A. and C.G. Young. 1992. Seeds of woody plants in North America. Dioscorides Press, Portland, Ore.

Young, J.A., D.E. Palmquist, and R.A. Evans. 1991.. Temperature profiles for germination of big sagebrush seeds from native stands. J. Range Manage. 44:385-390.

Young, J.A., B.L. Kay, H. George, and R.A. Evans. 1980. Germination of three species of Atriplex. Agron.J. 72:705-709. 